Bлияние давления на поглощение гапогенидов серебра I

\title{
THE EFFECT OF PRESSURE ON THE OPTICAL ABSORPTION OF SILVER HALIDES I.
}

(Abstract of preceding paper)

\author{
KAREL VACEK \\ Institute of Physics, Charles University, Prague
}

\begin{abstract}
A study was made of the effect of pressure on the absorption edge of pure single crystals of $\mathrm{AgBr}, \mathrm{AgCl}, \mathrm{AgI}$. The crystals were deformed (uni-axially, unsymmetrically) at room temperature; absorption was measured at $-180^{\circ} \mathrm{C}$. The absorption edge shifted to the ultra-violet end of the spectrum with growing pressure (e. $\mathrm{g}$. for a load of $20 \mathrm{~kg} / \mathrm{cm}^{2}$ there was a shift of $0.03 \mathrm{eV}$ with $\mathrm{AgCl}, 0.04 \mathrm{eV}$ with $\mathrm{AgBr}$ and $0.005 \mathrm{eV}$ with AgI). In AgI crystals this shift is an order smaller than with AgCl and AgBr crystals. At higher pressures $\left(>70 \mathrm{~kg} / \mathrm{cm}^{2}\right)$ the shift attains a constant value. In accordance with Billig's paper the observed phonomenon was explained by the dilatation of the forbidden zone as a result of decreasing the lattice constant by pressure. Assuming that the relative change in the lattice constant da/a as a result of the pressure will be of the same order as the following relative change in the excitation energy of the valency electrons d $E / E$, it then holds that$$
\mathrm{d} E / E=k \mathrm{~d} a / a,
$$

where $k$ is a constant characteristic of the given material. The partial change in the excitation energy can be determined from the shift of the absorption edge and the compressibility of the given material can be substituted for $\mathrm{d} a / a$. The value of the constant $k$ can then be determined. In this case the following values of the constant $k$ were obtained for the different crystals: $\mathrm{AgCl}-21.8, \mathrm{AgBr}-8.3, \mathrm{AgI}-3.1$.

Received 2. 10. 1957.

$$
\text { Jumepamypa, - References }
$$

[1] Höhler G.: Ann. Phys. 4(1949), 371.

[2] Toy F. C., Harrison G. R.: Proc. Roy, Soc. A 127 (1930), 613.

[3] Moser F., Urbach F.: Phys. Rev. 10 (1956), 5, 1519.

[4] Gilleo M. A.: Phys. Rev. 91 (1953), 534.

[5] Kaiser W.: Z. Phys. $132(1952), 497$.

[6] Vacek K.: Чехосл. физ. жүрн. 8 (1958), 2, 226.

[7] Billig E.: Proc. Phys. Soc. A 64 (1951), 878. 